\title{
In Memoriam: Alan Howard, MA, PhD, FRIC (1929-2020): as I knew him
}

\author{
George A. Bray ${ }^{1}$
}

Received: 14 August 2020 / Revised: 19 August 2020 / Accepted: 3 September 2020 / Published online: 9 October 2020

(c) The Author(s) 2020. This article is published with open access

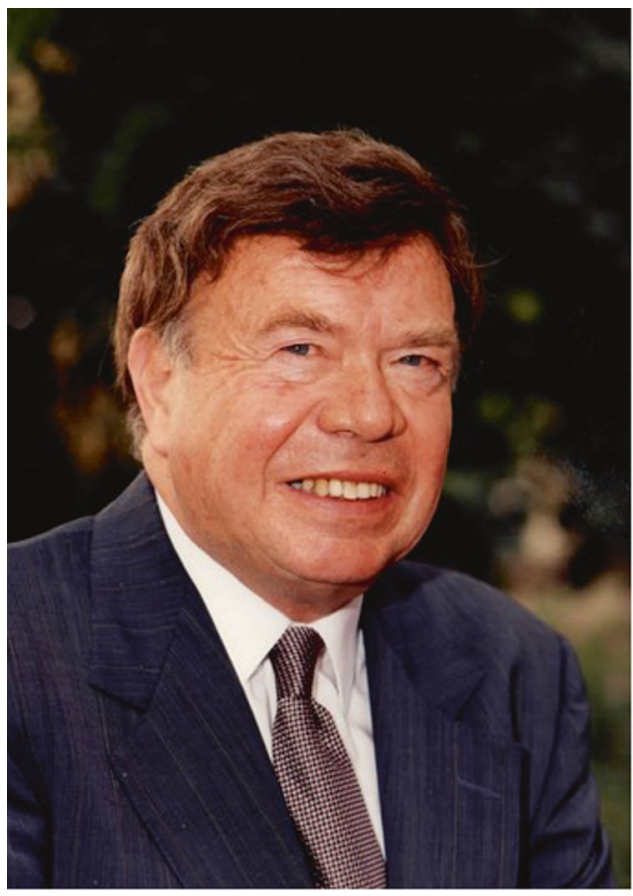

Few, if any, academic scientists have had as much impact on the field of obesity, or touched as many lives of patients with obesity, as Dr. Alan N. Howard.

\section{Dr. Howard's beginning: before I met him}

According to the obituary in the London Times [1], "Alan Howard was born in Norwich, England in 1929 to Leonard

George A. Bray

George.Bray@pbrc.edu

1 Pennington Biomedical Research Center, Clinical Research, Baton Rouge, LA, USA
Howard, who worked in a mill, and Elsie (née Atkins), who was a tailor. After his father lost a finger in an accident at the mill, he used the compensation money to build up a tailoring business with his wife. After World War II they opened the Victory Café in Norwich. Alan was educated at City of Norwich grammar school where he played chess for the Norfolk and Norwich Club. At age 17, in 1946, he won the newly created Junior Championship Cup. He was also a keen photographer with his own darkroom.

Howard won a place at Downing College in Cambridge, England in 1948 where he studied Natural Sciences. He was elected to the Arthur Paul Saint Scholarship at Downing College in July 1952, a scholarship he held for 2 years. Dr. Howard's PhD was approved on 30 Nov 1954 for research on 'the reaction of diazonium compounds with amino acids and proteins and its application to serological problems'. He received both his MA and PhD on 22 Jan 1955.

Dr. Howard's academic career was spent entirely at Cambridge University in England where he worked in various departments, including the Medical Research Council Unit of Nutrition (also known as "the Dunn"), the Department of Pathology and the Department of Medicine. One theme in Dr. Howard's career was the study of atherosclerosis where he served as one of the organizers and editors of the proceedings from the 1st International Symposium on Atherosclerosis held in Athens in 1966. Thus, began his involvement with organizing and publishing International Symposia. The next international symposium that Alan organized and published was the 1st International Congress on Obesity [2] held under his chairmanship in London in 1974. This was followed 6 years later by the first of four International Symposia in Clinical Nutrition which was held in London in 1980, and whose proceedings he edited [3].

\section{Dr. Howard: organizer in the field of obesity}

My introduction to Dr. Alan Howard was through a small book he edited for the Obesity Association in collaboration 
with Dr. Ian McLean Baird, MD, MRCP, a colleague with whom Alan was to have many life-long interactions [4]. The Obesity Association in the United Kingdom began in 1961 and had its inaugural meeting in May 1967. The meeting in 1968 was organized largely by Dr. A.N. Howard of Cambridge and Mr. D.S. Miller of Queen Elizabeth College, London together with Dr. I. McLean Baird, a consultant physician at West Middlesex Hospital in London. Professor W.J.H. Butterfield became President of the Association in September 1967 and chaired the one-day symposium held in October 1968 that was published in 1969. During this symposium, Alan Howard presented a paper on "Dietary Treatment of Obesity" which presaged things to come. We will return to Dr. Howard's discussion of Dietary Treatment in discussing the Howard/Cambridge Diet. The publication of this book by Baird and Howard appeared as I was beginning my own career in obesity. This was, to my knowledge the first monograph covering presentations by experts all of whom were interested in the problem of obesity. The Association for the Study of Obesity was also the first academic organization devoted to study of obesity that I know of.

Two years later, in April 1972, both Alan and I were invited to a scientific meeting in Germany, and from that time forward we were life-long friends. During this meeting the two of us took an afternoon off to drive to Bingen-amRhine, a lovely town on the Rhine River. It was a delightfully warm afternoon as we sat having lunch, while talking about the future of obesity and obesity research. Fresh from the success of the First Obesity Association meeting, later called the Association for the Study of Obesity, Alan was filled with ideas about the future of obesity, and so was I. It was a synergistic meeting from which three themes emerged. The first theme was the need for more national associations interested in the problems of obesity. Over the next 10 years a number of Obesity Associations formed in many countries with the North American Association for the Study of Obesity being one which held its first meeting at Vassar College in October 1982. The second theme was the need for international gatherings with obesity as their focus. The first in 1973 was sponsored by the Fogarty Center at NIH and was held in Bethesda in the fall of that year. One year later, in 1974, the 1st International Congress of Obesity was held in London, England at the Royal College of Physicians and chaired by Dr. Howard [3]. There was an overflow crowd of more than 500 people in attendance. This was followed 4 years later by the 2nd International Congress on Obesity held in Washington DC and organized by yours truly which saw a doubling of the attendance. The third theme of our meeting was the recognition that a journal focused on obesity was needed. Two other journals had appeared: The Journal of Obesity began in 1964 and ceased publication in 1965;
Obesity and Bariatric Medicine was a newsletter published by and for the American Association of Bariatric Physicians, and not primarily a research journal [5]. No other scientific journals with obesity in their titles were being published at the time. During publication of the Proceeding of the First International Congress of Obesity, we talked to the publisher, Newman Publishing and John Libbey about whether they would be willing to publish this new journal called the International Journal of Obesity. They agreed, and thus in 1974 the International Journal of Obesity was born with Alan N. Howard and GAB as co-editors. The first issue appeared in January 1977 as a quarterly publication in a 6 by 8 -in. format. It gradually grew to a monthly publication as the stream of papers increased [6].

\section{The Howard/Cambridge diet}

At the 1968 meeting of the Obesity Association described above, Alan presented a paper on the Dietary Treatment of Obesity which, in retrospect, contained the seeds of the Howard/Cambridge diet [7]. The paper dealt with the trends in dietary management of patients with obesity as viewed from the perspective provided in 1968. The 1960s was the decade in which "fasting", as the ultimate low-calorie diet, became popular and was used in many locations worldwide. The shortcomings of fasting soon became apparent and included hypotension, hyperuricemia with kidney stones, loss of hair, and loss of body protein. It was this latter problem of protein loss on which Dr. Howard focused. It was becoming clear that protein supplements could reduce the losses of endogenous protein by supplying protein in the diet and these diets were thus often referred to as "Proteinsupplemented Modified Fasts" or PSMF.

Over several years in the late 1960s and much of the 1970s Alan and his collaborator Ian McLean Baird developed a low-calorie powdered formula diet with high-quality protein as a major constituent [8]. They used $330 \mathrm{kcal} / \mathrm{day}$ as the energy level in their diet. This level may have been stimulated by the significant weight losses seen in the Simeon's program which coupled a $500 \mathrm{kcal} /$ day diet with daily injections of human chorionic gonadotrophin (HCG). The HCG proved to be no better than placebo, but patients in this program experienced considerable weight loss when they adhered to the $500 \mathrm{kcal} / \mathrm{day}$ diet. The results of Howard and Baird's research were published in the first issue of the International Journal of Obesity in 1977 [8]. Shortly after this publication appeared, I received a letter from a professional colleague saying "wouldn't it be ironic if this diet proved to the basis of a commercial product", and that is what indeed transpired.

Dr. Howard tried to interest people in the United Kingdom in his diet, but to no avail. His break came when Eileen 
and Jack Feather from Pebble Beach, California discovered the diet. On a flight from California to his second home in England, Jack Feather read the report by Drs. Howard and Baird in the International Journal of Obesity. He saw the obvious potential and arranged a meeting with Dr. Howard. This resulted in an agreement in March 1979 that granted Jack and Eileen Feather the rights to market the diet in the USA and Canada. They named the diet the "Cambridge Diet" after the University where it was developed.

Jack and Eileen Feather met at the University of California in Berkeley, California after World War II. During college Jack developed polio, which produced long-lasting partial paralysis which stimulated his interest in muscle building. His wife, Eileen, nursed him through and together they went on to found the chain of Eileen Feather salons in California which was a major financial success. The proceeds from this business served to fund their work with Mark Eden Company which produced items to help people "slim-down". Thus, Jack Feather was very familiar with the weight loss business when he read Dr. Howard's paper.

The Cambridge Diet was introduced in America in 1980 and was initially made available by mail order. The Postal Service, with which the Feather's had previously been entangled came after them with claims of false advertising for the Cambridge Diet. In a consent decree, the Feather's abandoned the mail-order business and began training a multi-level sales force of "counsellors" who told their friends and acquaintances about the diet, sold them the diet products, and acted as mentors in using the Cambridge Diet. The Cambridge Diet rapidly spread across America from 25 counsellors in February 1981 to more than 150,000 counsellors by mid 1982. The Cambridge Diet was growing "like an expanding waistline" and soon millions of people were following it. Dr. Howard, who had the quiet voice and bedside manner of a family physician, became a celebrity. He undertook a speaking tour of America speaking to thousands of people in packed audiences. He said "I felt like a pop star".

Dr. Howard's visibility became an issue for the Publication Committee overseeing the International Journal of Obesity. It appeared to some that it was a conflict of interest for the Editor of the International Journal of Obesity to also be the front man for the Cambridge Diet from which he personally profited. Dr. Howard was encouraged to resign as Editor of the International Journal of Obesity, but he refused. As the Cambridge Diet grew ever larger the voices for his resignation grew louder and more persistent. In order to initiate an effective transition, I convinced Alan that we should both step down as Editors at the same time in a "Changing of the Guard" ceremony. This occurred in 1982 [9]. Per Bjorntorp from Sweden, who had played a pivotal role in 3rd International Congress of Obesity, accepted the role as the sole editor [5].

In 1980 Dr. Howard asked me if I would consult with the Feather's and advise them on selecting research projects that might show the safety and potential value of the Cambridge Diet. Over the 3 years that I served as a consultant they funded a number of academically based projects which used the "Cambridge Diet". They also funded a symposium on the use of Very Low Calorie Diets [10]. Licensing of the Cambridge Diet to the Feathers generated considerable royalties, and with these he established the Howard Foundation, an English charitable trust.

\section{The Howard Foundation}

The Howard Foundation was established in 1982. Between 1987 and 2009, the Foundation provided funds for three buildings at Downing College where Alan was an honorary Fellow, a Reception Hall, student accommodation and finally a Theatre. The Foundation owned the rights to the Cambridge Diet in the UK until it was sold in a Management Buyout in 2005. The main activity of the Foundation is now the licensing of its portfolio of nutriceutical patents, and the sales of nutriceuticals that were the result of the continued scientific work of Alan Howard in his later years -always the investigator with helping people as his driving force.

My last meeting with Alan was at the Howard Foundation in 2011. World Obesity, the umbrella group of national obesity associations that Alan and I had begun working toward nearly 40 years earlier, was holding an educational program called SCOPE at Downing College in early August, 2011. Alan invited me and my wife to be his guests at the meeting and he also invited Ian McLean Baird his long-term collaborator. Since the meeting was just after my 80th birthday, my wife and I came a few days early and spent my 80th birthday in Bray, England having dinner beside the Thames River in the Waterside Inn. We then spent one further night at Amberley Castle before arriving at the complex of buildings gifted by the Howard Foundation at Downing College in Cambridge. It was indeed a superb facility and a credit to Alan's good taste.

I close as I began with my farewell to an academic scientist and friend who did more for the field of obesity and for patients suffering from obesity than anyone else I know. May he rest in well-deserved peace.

\section{Compliance with ethical standards}

Conflict of interest Bray was a consultant to Jack and Eileen Feather and the Cambridge Diet until its bankruptcy in 1982. 
Publisher's note Springer Nature remains neutral with regard to jurisdictional claims in published maps and institutional affiliations.

Open Access This article is licensed under a Creative Commons Attribution 4.0 International License, which permits use, sharing, adaptation, distribution and reproduction in any medium or format, as long as you give appropriate credit to the original author(s) and the source, provide a link to the Creative Commons license, and indicate if changes were made. The images or other third party material in this article are included in the article's Creative Commons license, unless indicated otherwise in a credit line to the material. If material is not included in the article's Creative Commons license and your intended use is not permitted by statutory regulation or exceeds the permitted use, you will need to obtain permission directly from the copyright holder. To view a copy of this license, visit http://creativecommons. org/licenses/by/4.0/.

\section{References}

1. Alan Howard Obituary. Acuncular British nutritionist and philanthropist whose Cambridge Diet enabled millions of morbidly obese people to slim down. London, England: The Times Saturday; 2020.
2. Howard AN (Ed). Recent advances in obesity research I. London: Newman Publishing Ltd.; 1975.

3. Howard AN, Baird IM, editors. Recent advances in clinical nutrition I. In: Proceedings of the 1st International Symposium on Clinical Nutrition 9-11 July 1980 Royal College of Physicians, London. London: John Libbey and Co; 1981.

4. Baird IM, Howard AN, editors. Obesity: Medical and Scientific Aspects. Edinburgh: E. \& S. Livingstone Ltd; 1969.

5. Bray GA. Obesity research and medical journalism. Obes Res. 1995;3:65-71.

6. Howard AN, Bray GA. The age of obesity. Int J Obes. 1977;1:1-2.

7. Howard AN. Dietary treatment of obesity. In: Obesity medical and scientific aspects. Edinburgh: E. \& S. Livingstone Ltd, 1969, p. $96-111$.

8. Howard AN, Baird IM. A long-term evaluation of very low calorie semi-synthetic diets: an inpatient/outpatient study with egg albumin as the protein source. Int J Obes. 1977;1:63-78.

9. Bray GA, Howard AN. Changing of the guard. Int J Obes. 1982;6:225-6.

10. Blackburn GL, Bray GA, editors. Management of obesity by severe caloric restriction. Littleton, MA: PSG Publishing Co; 1985. p. 1-396. 